DOI: $10.7242 / 1998-2097 / 2018.2 .4$

УДК 78.07, 78.089

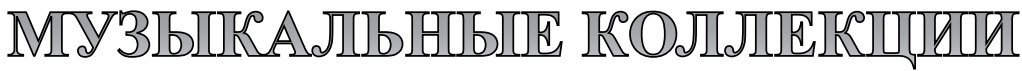

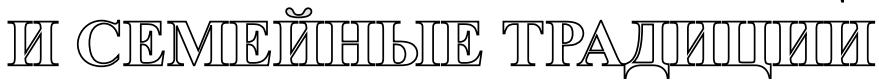

Л.М. Корж, Пермская музыкальная общественная организация «Классик»

Долгосрочный проект «Грибушинские ассамблеи» в Пермском научном центре УрО РАН (ныне ПФИЦ УрО РАН) начал осуществляться осенью 2015 года. Он пришел на смену концертным вечерам Клуба любителей классической музыки ПНЦ УрО РАН, двадцатилетняя история которых связана с возрождением традиций камерного музыкального исполнительства. Характерной особенностью вечеров Клуба (их состоялось более 200) было их объединение в тематические циклы, где органично соединялись творческие поиски талантливых пермских музыкантов, история особняка ПНЦ УрО РАН и наследие одного из выдающихся деятелей Серебряного века уральского архитектора и актера А.Б. Турчевича.

За минувшие годы старинный особняк (историческое название-Дом Грибушина, один из шедевров А.Б. Турчевича) стал привычным и родным для представителей академической науки, особенно для тех, чей досуг связан с классической музыкой. Накопленный учеными богатый научный и жизненный опыт, включенность в жизнь искусства послужили импульсом к обновлению сложившихся традиций. В новом фрормате вечеров, получивших название «Грибушинские ассамблеи», в фрокусе внимания находится личность ученого. В ассамблеях объединены два основных события: научно-популярное сообщение и концертная программа, эмоционально и содержательно связанная с научной частью вечера.

Ключевые слова: "Грибушинские ассамблеи», Музыкальная гостиная, нотные издания, семейные традиции, музыкальные коллекиии.

Интересна история ассамблей в России. Они были привнесены в социальную жизнь русского общества как «вольные собрания не только для забавы, но и для дела» одновременно с реформами Петра I через специальные указы и с подробным описанием правил поведения. Начало освоения европейского культурного опыта было положено в 1718 году. После смерти Петра Великого ассамблеи, введенные почти насильно и «поперек» привычного патриархального уклада, долгое время не проводились, но они немало способствовали появлению вкуса к светской жизни, публичному проведению досуга и, что немаловажно, развитию культуры балов по всей России. В XIX веке между ассамблеей и балом можно было ставить знак равенства. В XX веке балы (школьные, студенческие, новогодние и прочие) проводились, но иностранное слово assemblée (в переводе с французского - собрание), по понятным причинам, ушло из лексикона. В наши дни оно с полным правом используется, так как начала возрождаться, прежде всего в столичных городах России, традиционная универсальная форма ассамблей, сочетающая развлечения с просветительскими 


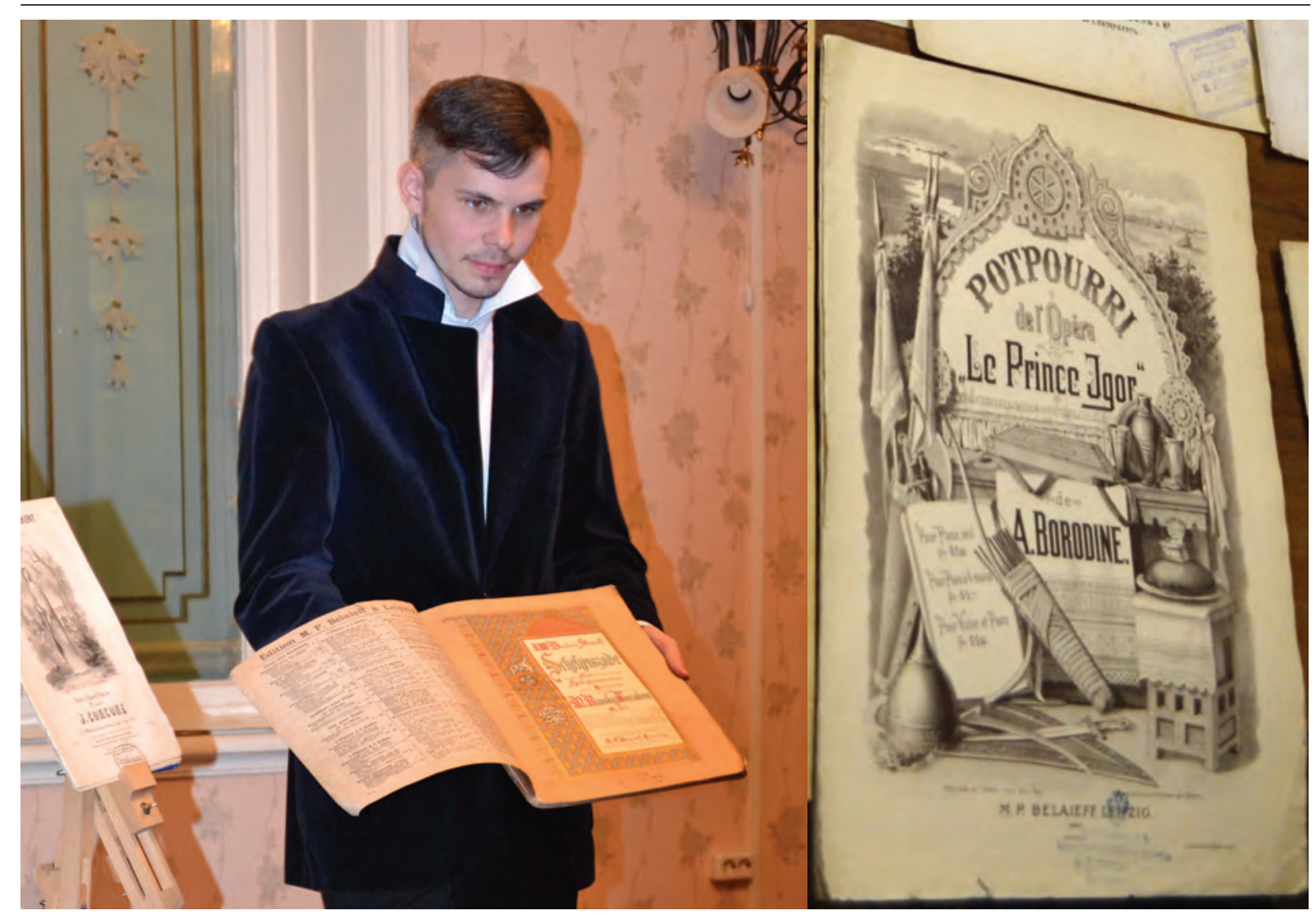

Виктор Дзевановский с нотами из своей коллекциии

и коммуникативными акциями. Ассамблея становится особой формой досуга, наполнение которой подчиняется конкретным целям $[1,2]$.

Инициативный проект «Грибушинские ассамблеи» открывает широкие возможности для знакомства с актуальными идеями, бесценным научным опытом пермских ученых и одновременно с искусством самых талантливых пермских исполнителей. Стремясь представить науку в «светском» варианте, инициаторы проекта Анастасия Вотинова и автор настоящей статьи опираются на мысли выдающихся отечественных ученых. Одна из таких «путеводных звезд» - академик В.И. Вернадский. Он писал: «И наука, и искусство - это два метода познания мира, общения человека с космосом. Они взаимно дополняются, а не исключаются». А высказывание М.В. Ломоносова: «Науки художествам путь показывают, а художества происхождение наук ускоряют», легло в основу «Грибушинских ассамблей».
Темы и программы ассамблей не повторяются, каждый вечер эксклюзивен. К примеру, доклад члена-корреспондента РАН А.В. Черных «Пермь: этническое измерение» соотносился с программой из вокальных сочинений, в основе которых - легко узнаваемые интонационно-ритмические комплексы, сложившиеся в той или иной национальной музыкальной культуре. Концертную программу для этого вечера подготовил ведущий солист пермской оперы (ныне - нижегородской оперы), обладатель выразительного и гибкого голоса Михаил Наумов (бас). А тема другого вечера, посвященного эпохе русского ренессанса, - «Пространство модерна» - получила роскошное музыкальное оформление из произведений композиторов Серебряного века С. Рахманинова, А. Скрябина, И. Стравинского в исполнении блестящего молодого пианиста, лауреата международных конкурсов Вячеслава Ронжина (Пермь - Москва). Такой формат проведения вечеров создает синергический эффект, 
усиливающий воздействие интеллекта и эмоций. Не последнюю роль в этом играет безупречная акустика Музыкальной гостиной и ее бережно сохраняемый исторический облик. (Подробно о возрождении культурно-исторических традиций, связанных с историко-архитектурным памятником, каким является бывший Дома Грибушина, можно прочитать в газете «Науке Урала», № 15 , август 2017, и № 8 , март 2004).

Ярким примером синергического объединения науки и музыкального искусства стал вечер «Эксклюзивные коллекции академика Ирины Борисовны Ившиной». Региональная профилированная коллекция алканотрофных микроорганизмов создавалась ею и ее коллегами годами напряженного исследовательского труда и в настоящее время признана национальным достоянием. Что это за микроорганизмы и почему необходимо иметь их обширную коллекцию для безопасности страны? - об этом шла речь в первой части вечера. Научные идеи, события, исторические факты, изложенные академиком ярко, доступно и увлекательно, произвели глубокое впечатление на публику. Во втором отделении прозвучала уникальная программа, составленная из пережившей блокаду Ленинграда семейной нотной коллекции И.Б. Ившиной. Не только для слушателей, но и для исполнителей она стала неожиданным открытием нового пласта музыки, сто лет назад популярной и любимой, а потом почти совершенно забытой. Почему так произошло? Чтобы ответить на этот вопрос, вернемся в удивительный по деятельной активности период, именуемый Серебряным веком.

На рубеже XIX-XX веков нотное издательское дело переживало настоящий бум, формируя эпоху широкого музыкального просвещения. Разобраться в этом сложном явлении помогла встреча с сотрудником Государственного Эрмитажа, коренным петербуржцем Виктором Дзевановским, принявшим приглашение участвовать в городском фестивале «Музыка старинных особняков». Он привез часть своей коллекции роскошно изданных нот, отражающих богатую музыкальную жизнь столичных аристократических салонов. В декабре 2013 года в Музыкальной гостиной ПНЦ с ним состоялась необычная встреча, положившая начало творческой работе с другими музыкальными коллекциями.

Из первого десятка крупных издательств в России кратко расскажем о трех самых известных, чей вклад в музыкальную культуру и сейчас невозможно переоценить. Нотное издательство П.И. Юргенсона открылось в 1861 году, и к началу XX века им было опубликовано около 25 тысяч музыкальных произведений. Юргенсон был основным издателем сочинений Чайковского, Аренского и других русских композиторов, ставших классиками еще при жизни. Он впервые в России выпустил полное собрание фортепианных сочинений Бетховена, Мендельсона, Шопена и Шумана. В 1918 году образцово налаженное издательство Юргенсона было преобразовано в государственное издательство «Музыка».

Особая страница в российской музыкальной культуре принадлежит меценату-лесопромышленнику и музыкальному деятелю М.П. Беляеву. В 1884 году он учредил ежегодную премию им. Глинки, в 1885 году - «Русские симфонические концерты», а также собственное издательство для публикации исключительно отечественных авторов. Отбирались произведения в Санкт-Петербурге при участии авторитетных музыкантов, печатались в Германии, распространялись как в России, так и в Западной Европе. В 1920 году издательство было переведено в Париж. Ноты, изданные Беляевым, в настоящее время пользуются большим спросом у коллекционеров, поскольку сборники прекрасно оформлены и могут удовлетворить самый взыскательный художественный вкус.

Несколько другое направление было у фирмы Ю.Г. Циммермана (ее деятель- 
ность в России завершилась в 1914 году). Она занималась торговлей инструментами своей фабрики, находившейся в Лейпциге. Там же печатались учебные пособия и ноты для различных музыкальных инструментов. Они способствовали широкому распространению ансамблевой игры, в том числе на русских народных инструментах.

Российское музыкальное образование традиционно опирается на огромное классическое наследие, поэтому великолепные издания Юргенсона, Беляева и Циммермана бережно сохраняются и составляют золотой фонд наших музыкальных библиотек.

Иная, более грустная судьба выпала на долю изданий, предназначенных для домашнего музицирования. Как известно, развлекательная музыка, особенно танцевальная, подвержена капризам изменчивой моды. А значит, с этими нотами, (к тому же стоили они относительно недорого), легко было расстаться. А вместе с хитами-однодневками волны исторических перемен унесли в забвение и подлинные шедевры.

К многочисленному кругу издательств, удовлетворявших в то время громадный спрос на легкую музыку и облегченные переложения популярных классических произведений, относилось московское издательство С.Я. Ямбора. Оно существовало с 1895 по 1917 год, а в 1911 году в Риме было удостоено Grand Prix. Нотный каталог этого издательства предлагал «лучшие музыкальные новинки, как то: любимейшие вальсы, романсы, арии из опер и оперетт, танцы, марши, куплеты, кроме того, самоучители и дешевые издания для всех инструментов». Все издания были карманного формата и стоили 10 копеек. Вот на эти изящно изданные ноты, ставшие раритетными, можно было полюбоваться, а потом и услышать новую-старую музыку на вечере «Эксклюзивные коллекции академика И.Б. Ившиной», который состоялся 12 декабря 2015 года. Ноты издательства Ямбора являются украшением и основной частью коллекции.

В концертную программу вечера были отобраны произведения разных жанров, образно и эмоционально способных передать атмосферу навсегда ушедшей эпохи. «Озвучена» пока лишь небольшая часть сохранившихся нот. Дирижер Владимир Никитенков, увлекшись темой, подробно и артистично представил коллекцию в целом и каждое произведение по отдельности. Это музыкальное путешествие во времени получило спустя год продолжение

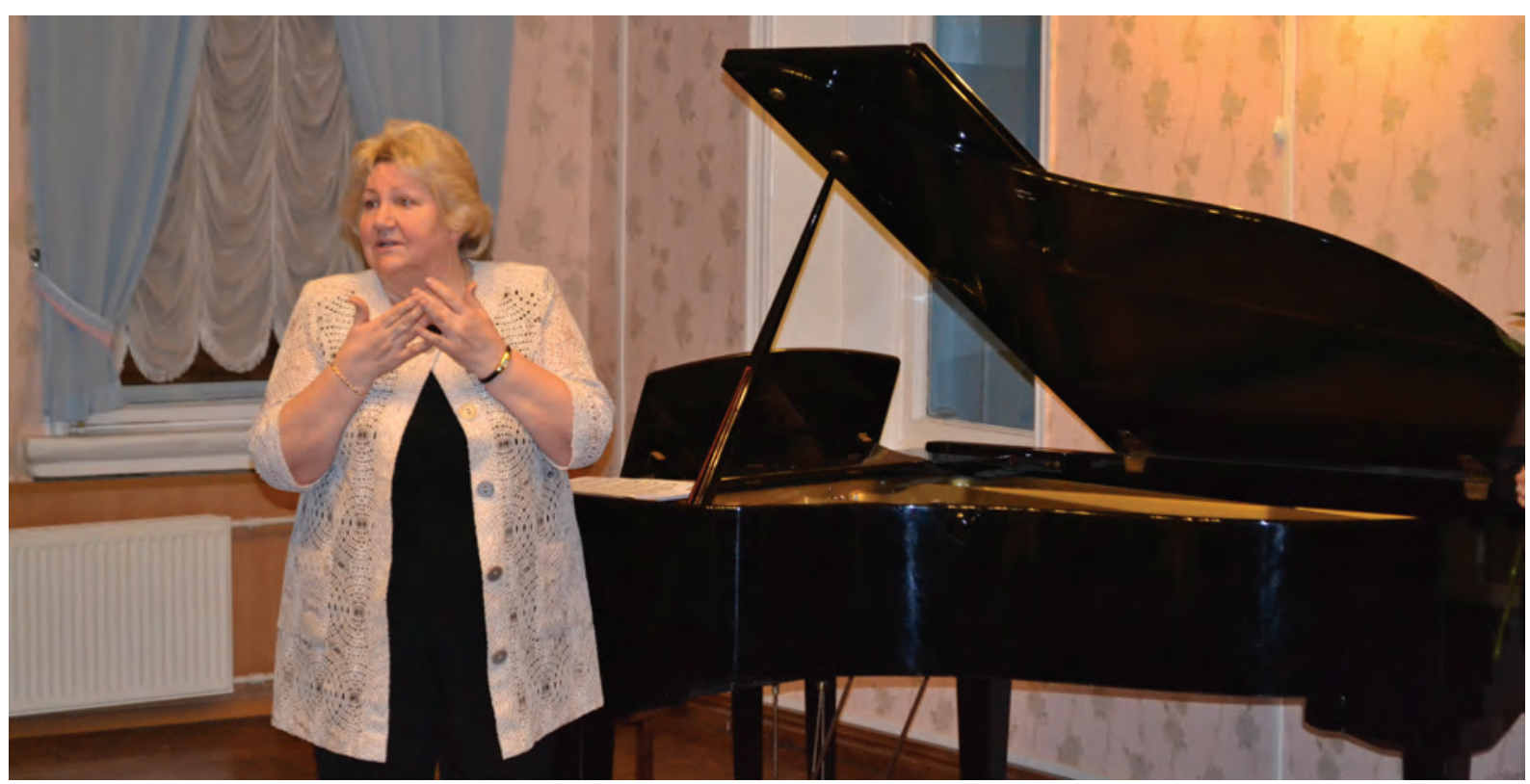

Ирина Борисовна Ивщина 
в спектакле-концерте Дома актера Пермского отделения Союза театральных деятелей РФ под названием «Давайте с веком вековать». В нем В. Никитенков выступил в качестве автора и режиссера. Отрадно отметить, что многие из прозвучавших произведений вошли в концертный репертуар исполнителей.

На этом знакомство с нотной коллекцией И.Б. Ившиной не закончилось. На взгляд инициаторов и авторов проекта «Грибушинские ассамблеи», любое интересное и редкое культурное явление заслуживает быть рассмотренным с разных точек зрения. После предыдущего вечера остался открытым вопрос о том, кто собрал и кто сумел сберечь коллекцию. Поэтому через некоторое время мы вернулись к семейной нотной коллекции.

3 марта 2018 года в рамках «Грибушинских ассамблей» состоялся особенный вечер. Первая часть его была посвящена не науке, а семейным культурным традициям ее представителей и рассказу о том, как вместе с любовью к научному творчеству и музыке передавались понимание жизни и семейные ценности. Здесь самое время сказать о том, что камерная атмосфера Музыкальной гостиной располагает к доверительному общению и эмоциональной открытости. Поэтому семейная фотохроника, не говоря уже о музыке, воспринимается естественно и с большим интересом.

Тема «Коллекция как зеркало эпохи», предложенная Ириной Борисовной Ившиной, в полной мере соответствовала выступлению Григория Федоровича Масича, зав. лабораторией ИМСС ПФИЦ УрО РАН, унаследовавшего от отца коллекцию русских народных инструментов. На один вечер в Музыкальной гостиной был собран, условно говоря, небольшой музейный фонд: домры, мандолины, балалайки и ноты в рамах под стеклом.

Ирина Борисовна начала свой рассказ с трогательной истории создания любимых и часто исполняемых в семье произведений. Она показала изящно изданные романс Г. Прянишникова «Хотя люблю я» и вальс «Раненый орел», написанный в госпитале унтер-офицером И. Кременецким с посвящением сестрам милосердия. Затем последовали фотографии из семейного архива. На одной из них - фотопортрет бабушки, Клавдии Алексеевны Маслиевой, петербурженки, которая и сохранила уже знакомую нам нотную коллекцию, унаследованную ею от матери. Имея высшее инженерное образование, она вместе с мужем, тоже конструктором, работала на Ленинградском

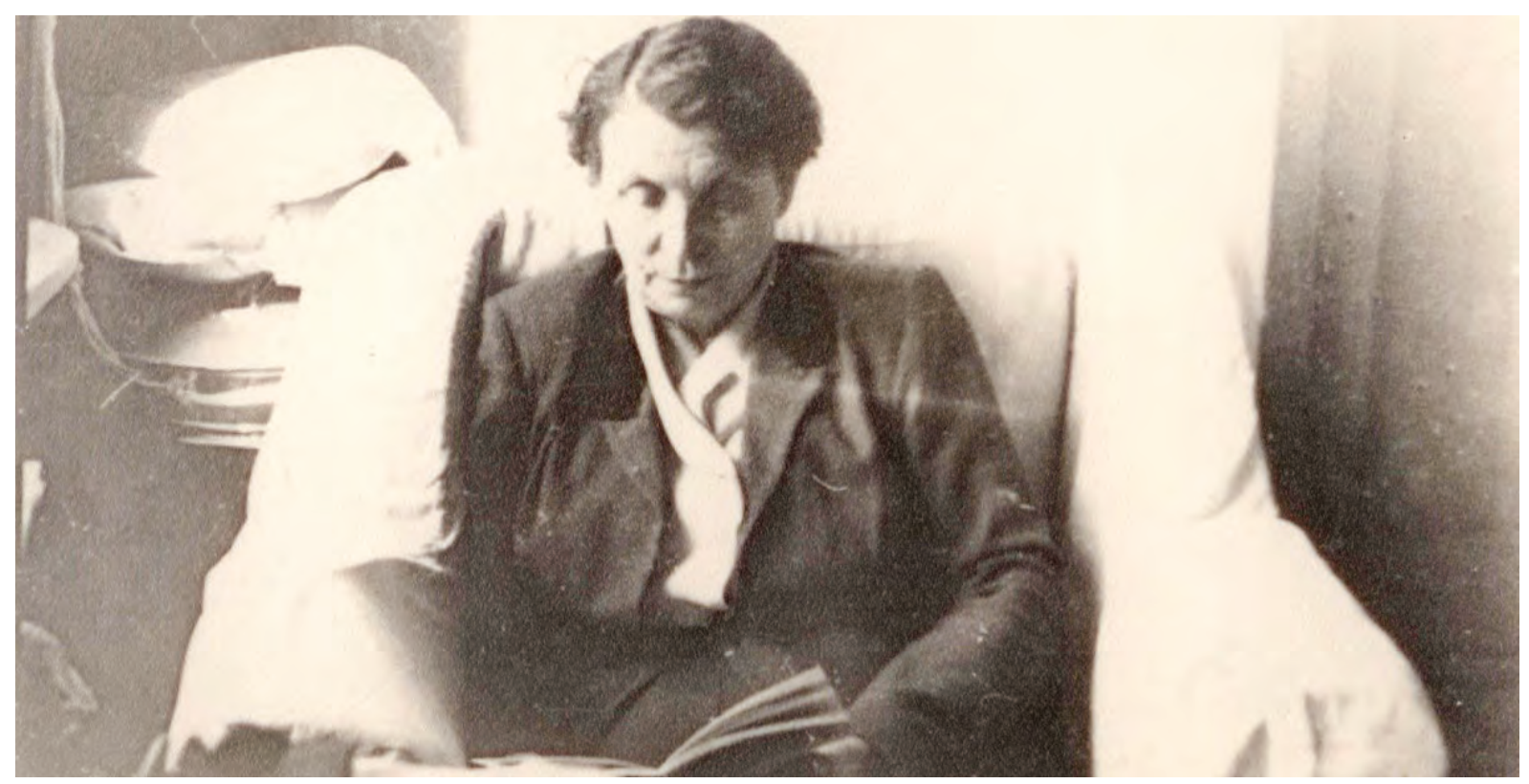

Клавдия Алексеевна Маслиева 
Кировском заводе. Муж погиб во время бомбежки, их дочь была эвакуирована в Свердловск и потому уцелела. А Клавдия Алексеевна пережила блокаду Ленинграда, все 872 дня. В семье ее звали «баба Каня» и жила она по-прежнему в Ленинграде, поэтому виделись с ней редко, во время каникул. Ирина Борисовна с сожалением заметила, что «поздно начинаем ценить мгновения общения с дорогими людьми». И далее: «Баба Каня была творческой личностью и сохранила любовь к музыке, живописи, много читала и хорошо знала историю России. Она принадлежала к тому поколению, в котором живы были еще традиции этикета. Было в ней внутреннее спокойствие, самообладание и безупречное чувство меры. Баба Каня владела очень хорошей русской речью, была строга и говорила, что надо иметь чувство ответственности перед словом». «Советы от бабы Кани» - отдельная страница семейной летописи. Вот некоторые из них:

- «Если отдавать себя целиком делу, тогда ждет непременный успех»;

- «Много трудись, учись»;
- «Надо уметь быть готовым к успехам, неудачам, к признательности и неблагодарности, к похвалам и порицанию, к поклонению. Главное при этом - не дать себя ни подкупить, ни запугать».

Представляя семейную фотохронику, Ирина Борисовна заметила: «Никакого семейного богатства у нас не было, но судьба вознаградила родителями». Не менее прекрасны ее слова о музыке: «При всех сложностях жизни каждый из нас может найти ту музыку, те стихи, литературные произведения, которые могут снять напряжение, утешить в горе, помочь в трудную минуту, когда чувствуешь несправедливость, и конечно - вдохновить на творческий процесс».

Музыкой и по-семейному завершилось выступление И.Б. Ившиной. Внучка академика Стася Шкуратова исполнила на рояле пьесу Д. Кабалевского из конкурсной школьной программы. Затем в виртуозной обработке пианиста Вячеслава Ронжина прозвучали когда-то очень популярные танцевальные пьесы из нотной коллекции Ирины Борисовны.

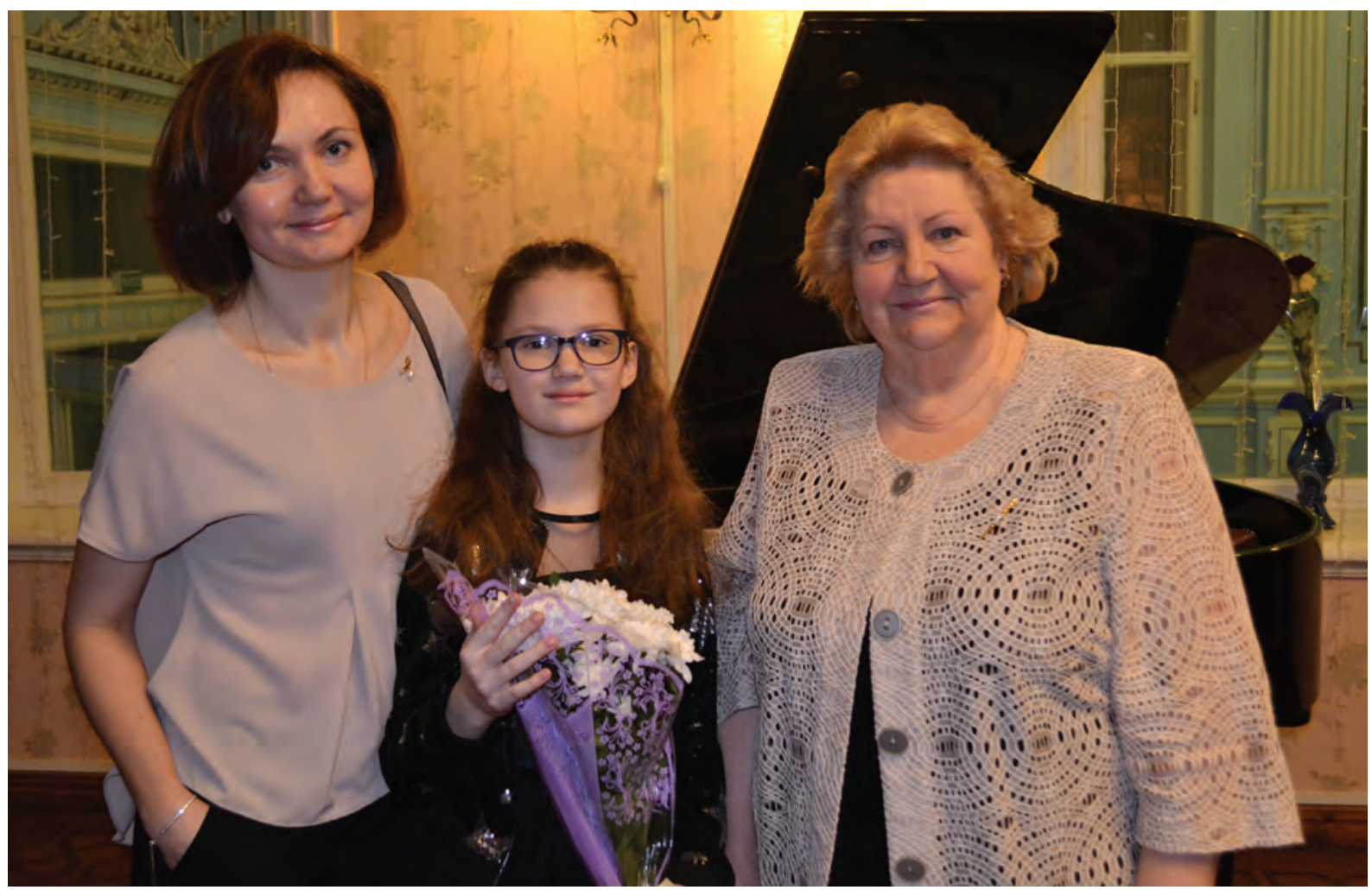

Ирина Борисовна Ившина с дочерью Еленой и внучкой Стасей 


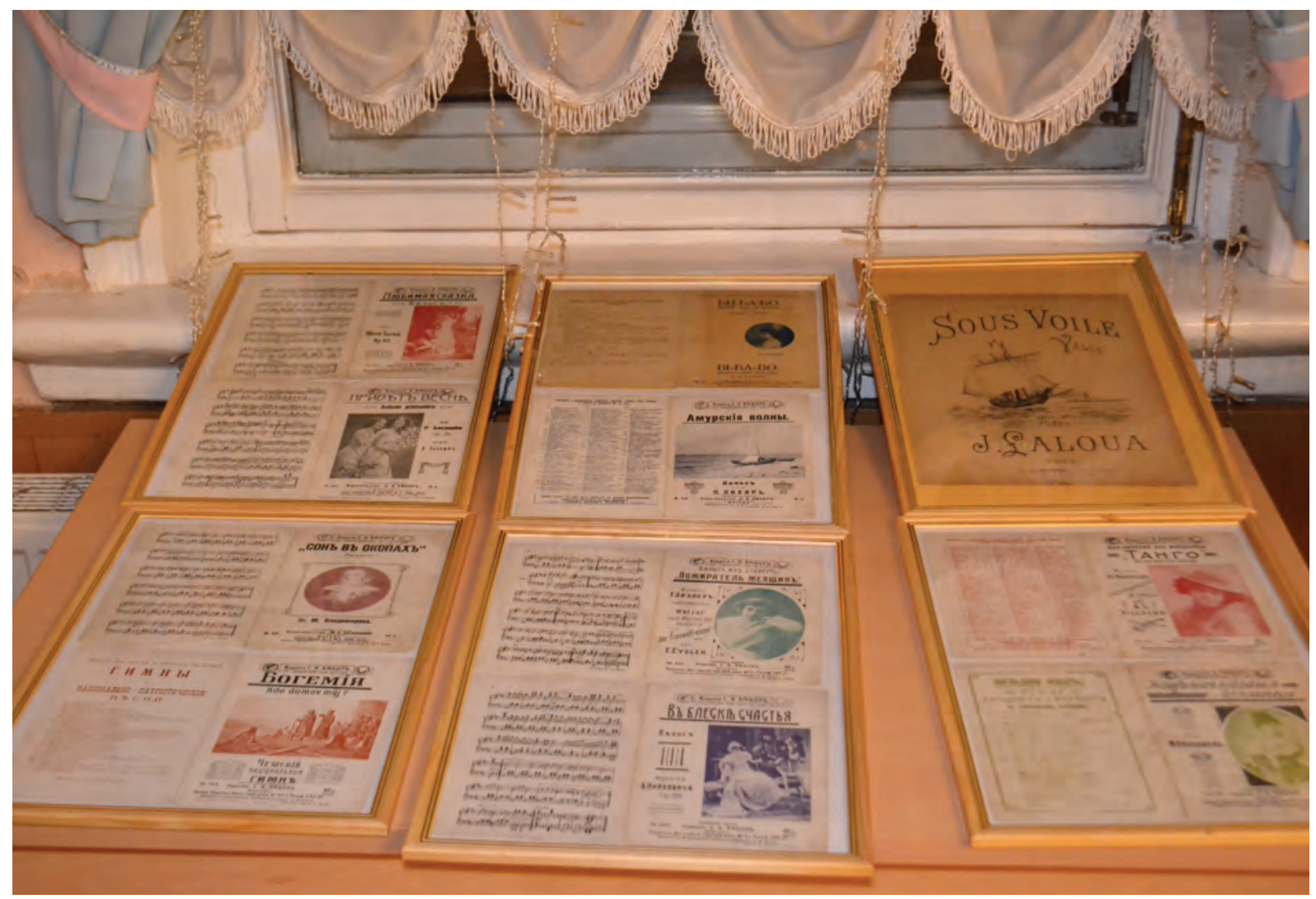

Ноты из коллекциии И.Б. Ившиной

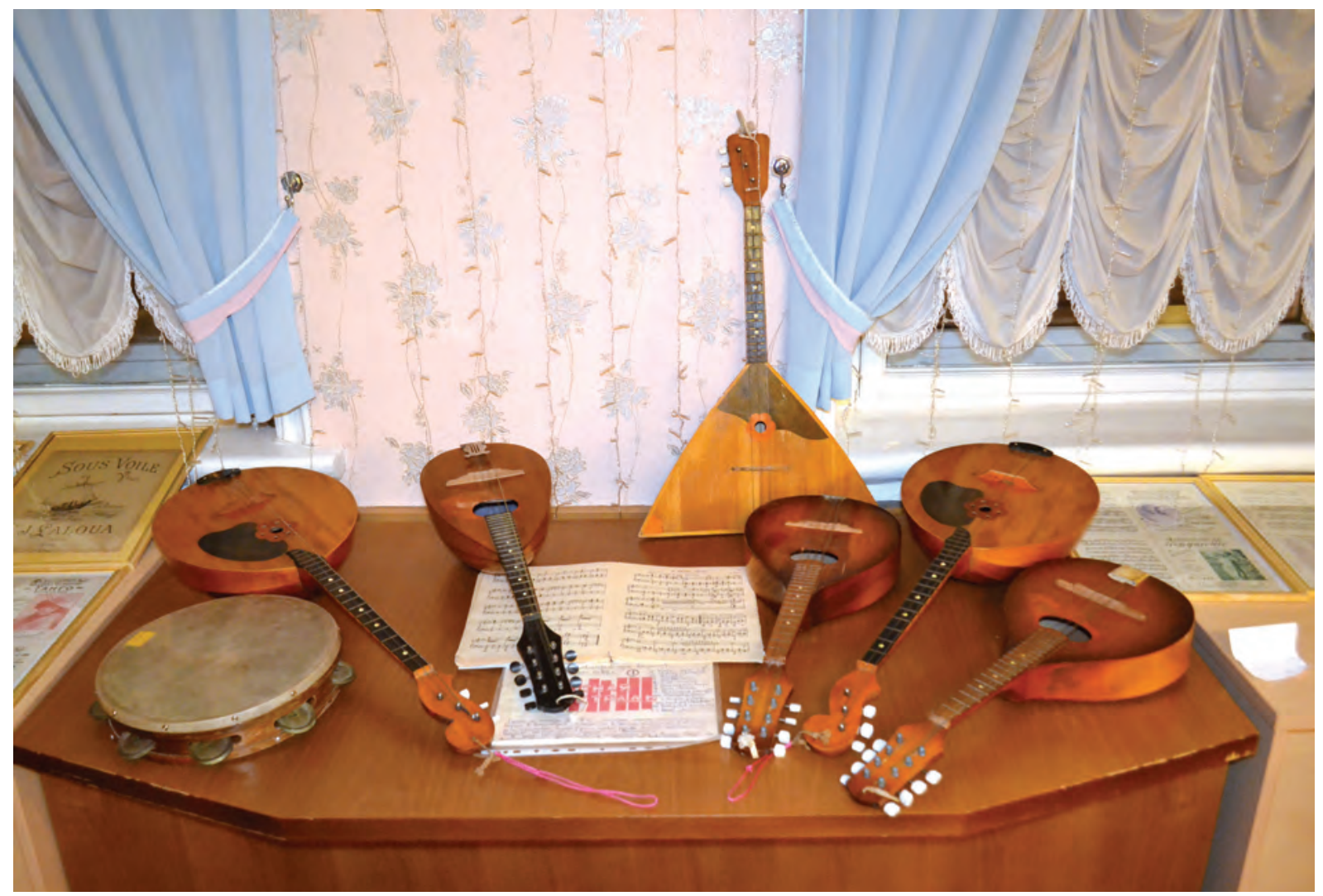

Инструменты из коллекиии Г.Ф. Масича 


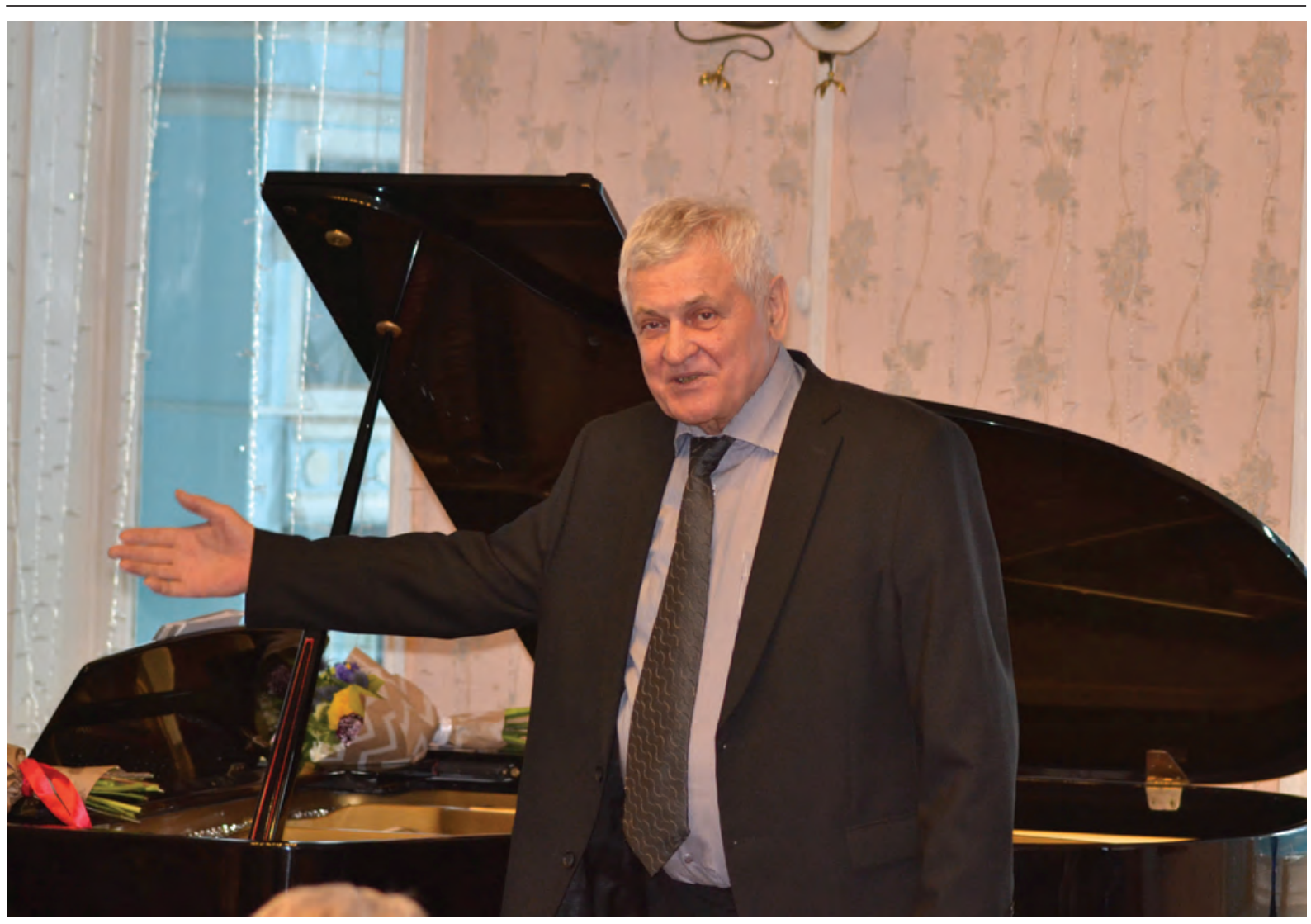

Григорий Федорович Масич

Выступление Григория Федоровича Масича было посвящено отцу - Федору Лукичу Масичу, который удивительным образом совмещал в своей жизни преподавание математики и физики в школе с разносторонней деятельностью руководителя школьного оркестра. Он сам расписывал инструментальные партии, поскольку ноты достать было сложно, сочинял аранжировки. Что-то из его нотной библиотеки сохранилось и теперь имеет статус авторской обработки.

Знакомя с семейными фотографиями, представленными под общим заголовком «Дед-оркестр», Григорий Федорович рассказал: «Основным инструментом отца была мандолина, он хорошо играл на балалайке, гитаре, аккордеоне. С оркестром выступал не только в школе, много было выездных концертов. Учитель математики и физики - это работа, а музыка - для души. Он и картины рисовал, и стихи сочинял, мебель для дома - все сам делал». К счастью, сохранились не только фотографии,

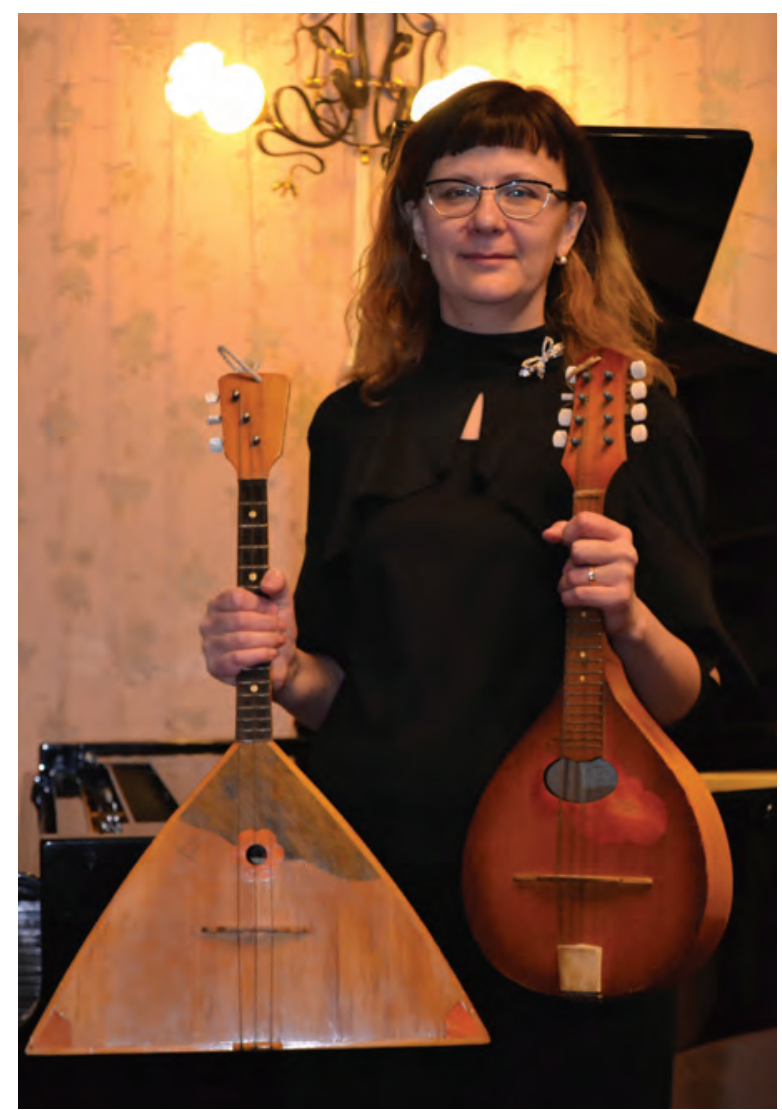

Анастасия Вотинова с инструмементами из коллекциии отиза 


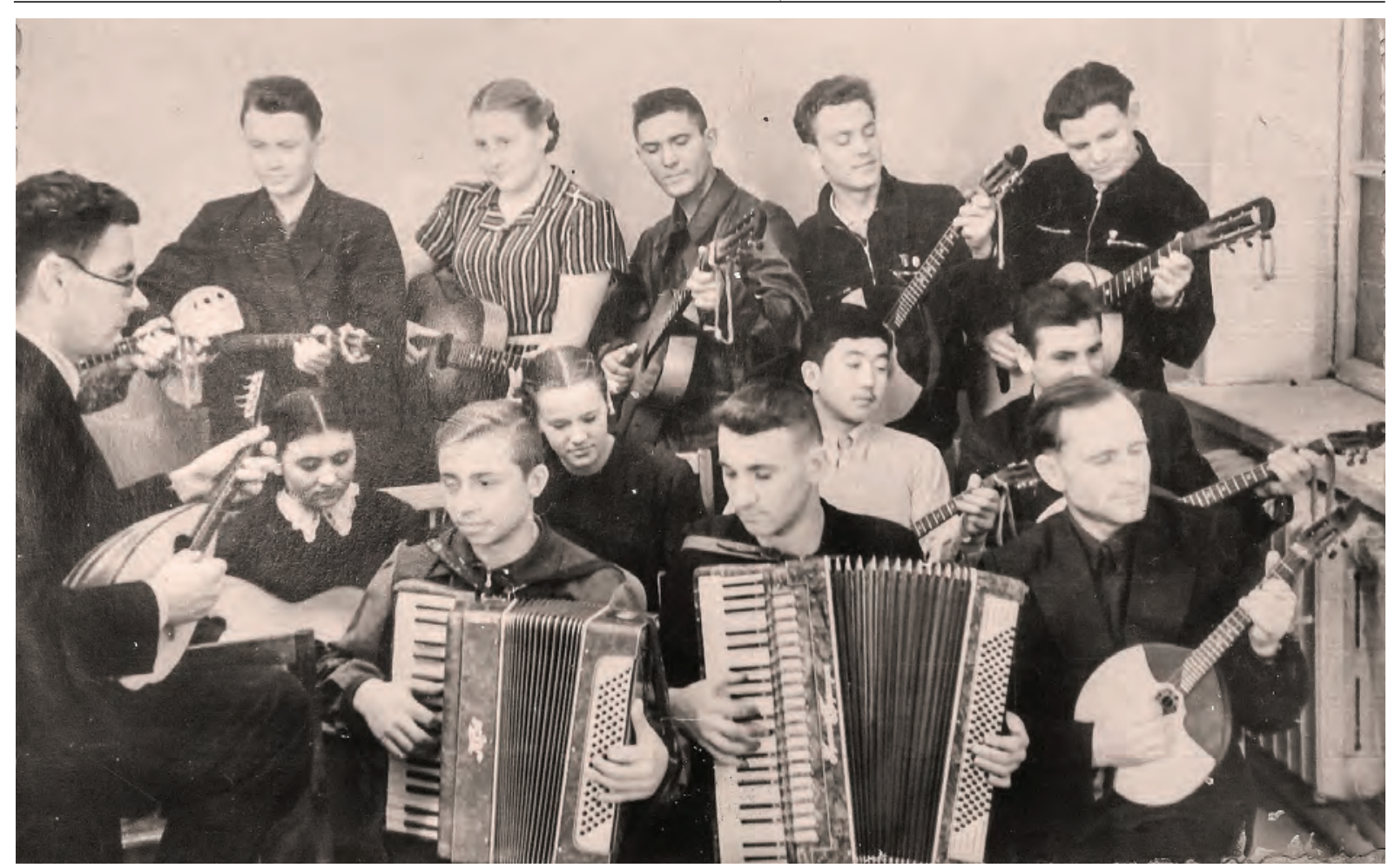

Федор Лукич Масич (слева) с участниками школьного оркестра

на которых Федор Лукич запечатлен с юными музыкантами, но и уникальная аудиозапись - исполнение школьным оркестром знаменитого марша В. Агапкина «Прощание славянки».

Профессиональных музыкантов в семье Григория Федоровича нет, но все играют на каком-либо инструменте: он сам - на аккордеоне, дочь Анастасия и внучка Аня на фортепиано, сын Алексей - на гитаре. Сохранились несколько бесценных видеозаписей, на одной из которых дед-оркестр, как по-прежнему называют его внуки, играет с ними в ансамбле любимый в семье

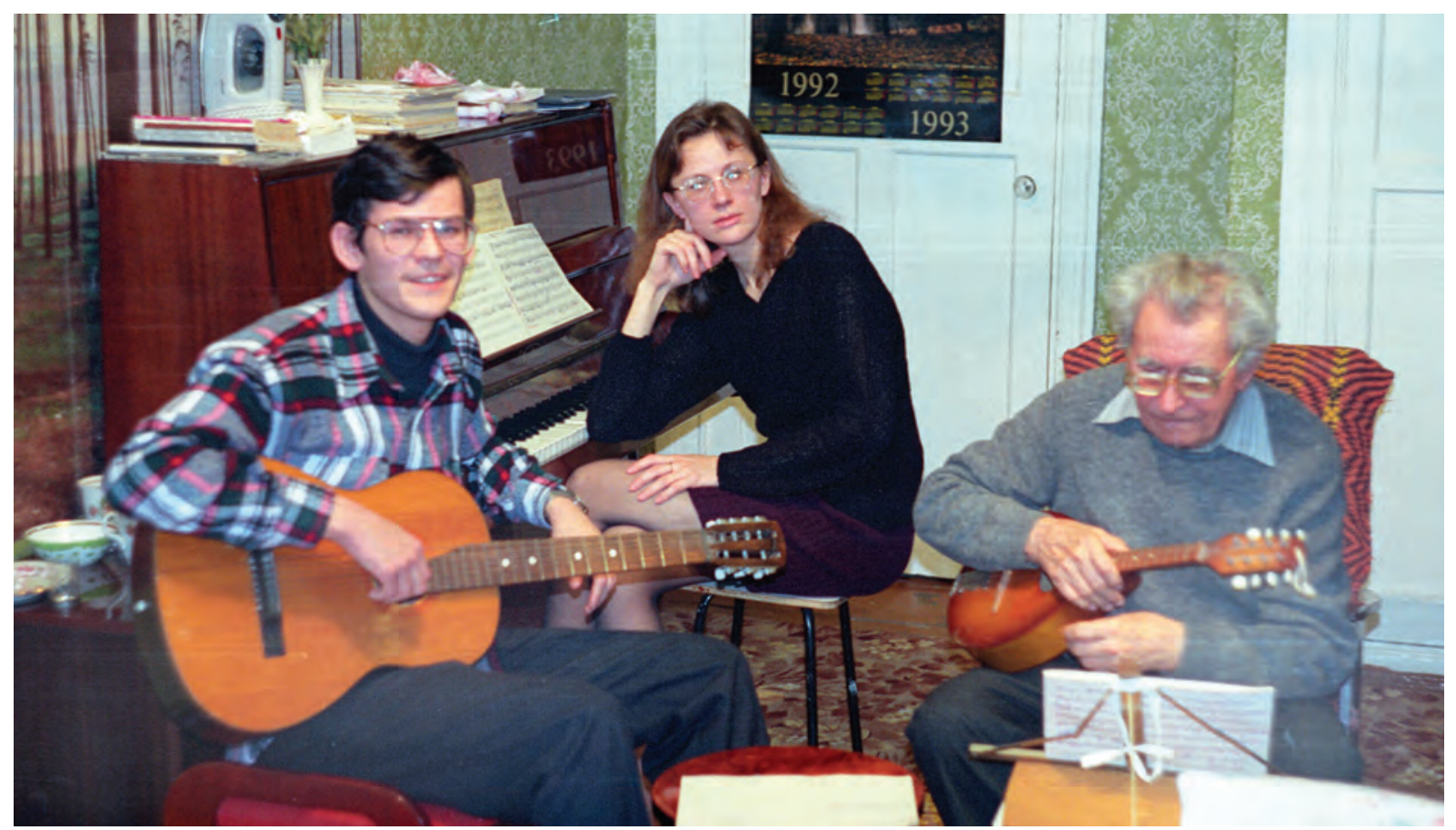

Семейное трио: Алексей, Анастасия, Федор Лукич, 1993 
вальс «Разбитая жизнь» М. Кюсса, автора знаменитого вальса «Амурские волны». Организация и проведение семейных музыкальных вечеров, которым предшествовала долгая и тщательная подготовка под неизменным руководством Федора Лукича, были отдельной главой в жизни семьи Масич. В память о нём прозвучали вальс «Разбитая жизнь» и Чардаш Монти в скрипичном исполнении М. Зонтовой, завершив выступление Г.Ф. Масича. Было в этих звуках нечто завораживающее и на мгновение делающее время почти осязаемым: далекое и близкое, живущее в сохранившихся нотах и советах бабушки, отцовских картинах и звуках его оркестра, любимых песнях и книгах...

По сложившейся традиции «Грибушинских ассамблей», второе отделение было концертным. Лауреаты всероссийских и международных конкурсов Мария Зонтова (скрипка, Москва) и пианист Вячеслав Ронжин (Пермь-Москва) подготовили интереснейшую программу из произведений Баха, Моцарта, Брамса, Пярта, Гласса и Пьяццоллы. Она была прекрасно воспринята публикой. Музыка разных эпох и стилей, блестяще исполненная талантливыми молодыми музыкантами, придала всему рассказанному и услышанному на этом вечере необычайную глубину.

Фото Павла Корж
В конце статьи, завершая тему музыкальных семейных коллекций, приведем цитату, взятую из выступления И.Б. Ившиной. Это строки из письма русского полководца М.И. Кутузова: «Весь вопрос счастья - коллекционировать хорошее, что есть в мире... в душе своей, в других людях... Но это будет обман, нас возвышающий, скажете Вы. Нет, это будет истина, нас спасающая».

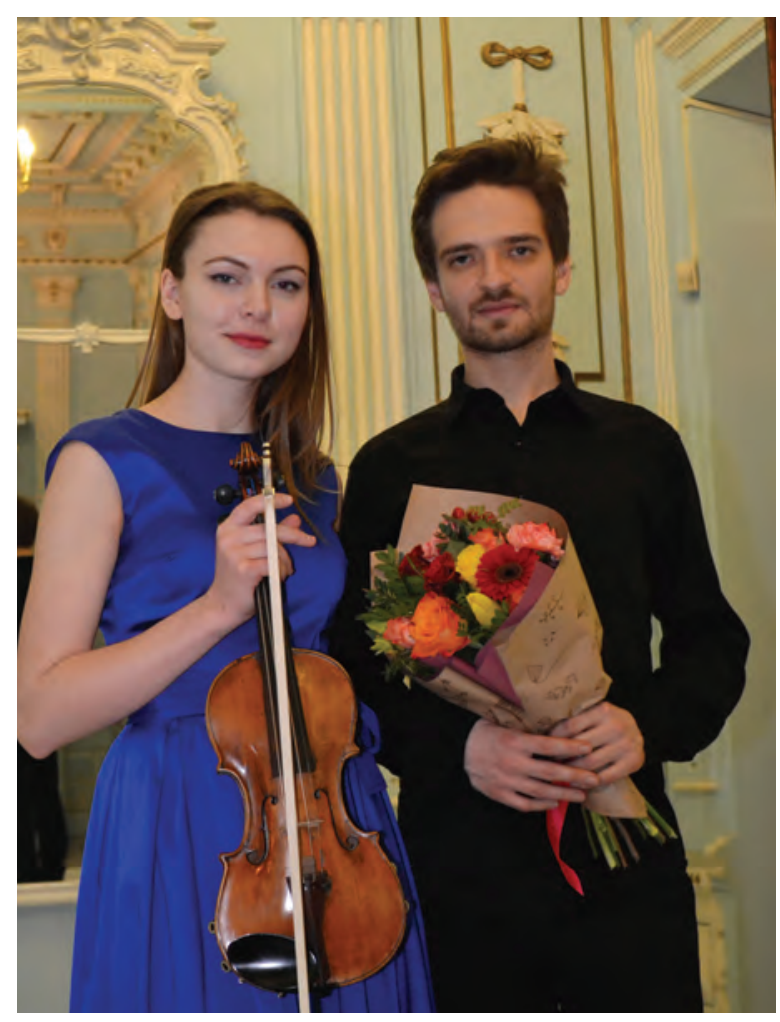

Мария Зонтова и Вячеслав Ронжин

\section{Библиографический список}

1. Культурно-досуговая деятельность: учеб. /под науч. ред. акад. РАЕН А.Д. Жаркова и проф. B.М. Чижикова. - М.: МГУК, 1998. - 461 с.

2. Комиссаренко С.С. Культурные традиции русского общества / С.С. Комиссаренко. - СПб.: СПбГУП, 2003. - 304 c. 


\title{
MUSICAL COLLECTIONS \\ AND FAMILY TRADITIONS
}

\author{
L.M. Korzh
}

Perm musical public organization «Klassik»

The long-term project «Gribushin's Assemblies in the Perm Scientific Center of the UB RAS» (now PFRC UB RAS) was launched in autumn 2015. It replaced the concert evenings of the Classical Music Fan Club of the PSC UB RAS. The twenty-year-old history of those evenings is associated with revival of the traditions of chamber music performances. The characteristic feature of the Club's evenings (more than200) was the unification into thematic cycles where the creative pursuits of talented Perm musicians were ideally combined with thehistoryofGribushin'mansionand theworkofoneof prominentarchitectsA.B. Turchevich. Over the past years the old Gribushin's House, one of A.B. Turchevich's masterpieces, has become a traditional place for meetings of representatives of academic science, especially for those whose leisure-time is associated with classical music. In the new format of the Gribushin's Assemblies it is the personality of a scientist that is in the focus. The assemblies combine two main events: a popular science report and a concert programme, the latter being emotionally and contextually related to the scientific part of the evening.

Keywords: Gribushin's Assemblies, Music hall, music editions, family traditions, musical collections.

\section{Сведения об авторе}

Корж Людмила Михайловна, председатель правления, Пермская музыкальная общественная организация «Классик», 614900, г. Пермь, ул. Ленина, 13А; e-mail: klassik.perm@gmail.com 